\title{
The earthworm's diversity and their relationship to the soil physicochemical properties under the stands of perennial plant at the Mount Merapi forest, Yogyakarta, Indonesia
}

\author{
SRI MINARSIH ${ }^{1}$, EKO HANUDIN ${ }^{2, \boldsymbol{v}}$, MAKRUF NURUDIN ${ }^{2}$ \\ ${ }^{1}$ Assessment Institute for Agriculture Technology (AIAT) Central Java. Jl. Soekarno Hatta Km. 26, No. 10, Tegalsari, Bergas, Semarang 50552, Central \\ Java, Indonesia \\ ${ }^{2}$ Department of Soil Science, Faculty of Agriculture, Universitas Gadjah Mada. Jl. Flora No. 1, Bulaksumur, Sleman 55281, Yogyakarta, Indonesia \\ Tel./fax.: +62-274-548814, `email: ekohanudin@ugm.ac.id
}

Manuscript received: 16 Februray 2021. Revision accepted: 19 May 2021.

\begin{abstract}
Minarsih S, Hanudin E, Nurudin M. 2021. The earthworm's diversity and their relationship to the soil physicochemical properties under the stands of perennial plant at the Mount Merapi forest, Yogyakarta, Indonesia. Biodiversitas 22: 3237-3244. The study was to propose earthworm as bioindicator and its correlation to the soil physicochemical properties underneath some perennial plants. Soil samples and earthworm observation was taken out at a depth of 0-10 cm and 10-20 cm under the stands of Acacia decurrens, coffee, Albizia chinensis, bamboo, snake fruit, and Acacia mangium. Soil moisture, temperature and Physico-chemical properties were measured, such as texture, $\mathrm{pH}$, organic $\mathrm{C}$, mineralized $\mathrm{C}$, total $\mathrm{N}$, mineralized $\mathrm{N}$, available $\mathrm{P}$, and base cations $(\mathrm{Ca}, \mathrm{Mg}, \mathrm{K}, \mathrm{Na})$. The results revealed that the earthworms density underneath of the stands of coffee was 105.4 ind. $\mathrm{m}^{-2}>$ snake fruit 92.6 ind. $\mathrm{m}^{-2}>$ Albizia chinensis 66.7 ind. $\mathrm{m}^{-2}>$ A. decurrens $\approx$ bamboo 40.7 ind. $\mathrm{m}^{-2}>$ A. mangium 37.0 ind. $\mathrm{m}^{-2}$. The dominant species of the earthworms found at a depth of 0-10 cm consisted of four species, namely: Pheretima hamayana, Pheretima californica, Eudrillus eugeniae, and Eiseniella tetraeda. Meanwhile, the earthworms diversity underneath the stands of coffee was $\mathrm{H}^{\prime}=1.26>$ A. mangium $\mathrm{H}^{\prime}=1.03>$ Albizia chinensis $\mathrm{H}^{\prime}=0.69>\approx \mathrm{H}^{\prime}=0.69>$ bamboo $\mathrm{H}^{\prime}=0.59$. The soil physicochemical properties was positively correlated to the earthworms density was $\mathrm{C}$-mineralized $(\mathrm{r}=0.823) \geq$ soil moisture $(\mathrm{r}=0.585) \geq$ available $\mathrm{K}(\mathrm{r}=0.529) \geq$ available $\mathrm{Ca}(\mathrm{r}=0.505) \geq$ available Mg (0.494). The results could be concluded that labile organic carbon, water, and alkaline cations were the important factors in improving soil biological fertility in the active volcano area.
\end{abstract}

Keywords: Earthworms, Merapi volcano, perennial plants, soil physicochemical properties, and diversity index

\section{INTRODUCTION}

The big eruption of 2010 has damaged the biotic and abiotic environment around Merapi Volcano (Surono et al. 2012). The process of soil fertility and plant recoveries has been ongoing since the eruption, but there was a lack of information on the indicators used to view the recovery process. The Cangkringan subdistrict as part of the upland areas seriously affected by the eruption of Merapi volcano in 2010 (Jousset et al. 2013). The effort to improve the land has been done via a reforestation program with various species of plants. It was expected that the plants could prevent landslides and erosions (Idjuddin et al. 2012) and also contribute to fertilize the soil underneath the plants (Yatso and Lilleskov 2016). It is expected that the leaf blossom of the plant will enrich the soil organic matter content so that the process of soil fertility recoveries will take place faster (Agus and Wulandari 2012).

The availability of organic matter in the soil would stimulate the propagation of fauna in the soil such as earthworms (Cesarz et al. 2016; Singh 2018). The earthworms represented soil organisms that played an important role in improving soil productivity (Blouin et al. 2013). They played an important role as organic matter decomposers (Frousz 2017) and soil fertilizing agents through their activities in improving the soil physical, chemical and biological properties (Chauhan et al. 2014; Singh et al. 2016a). Additionally, they also served the function of bioameliorant or soil-improving biological organisms (Chauhan 2014). The presence of the earthworms in an ecosystem might be considered as the bioindicator of soil fertility (Peres et al. 2011; Bartz et al. 2013).

The population of the earthworms was closely correlated to the condition of the environment where they lived (Kanianska et al. 2016). Their population density depended on the soil's physical and chemical properties and sufficient availability of nutrients. Chauhan (2014) suggested that in addition to environmental factors such as soil moisture and temperature, physical and chemical factors of soil such as texture, structure, $\mathrm{pH}$, organic content, total nitrogen, available phosphor, and available potassium also influenced the number and the distribution of the earthworms. The study proposed earthworm as a bioindicator and its correlation to the soil physicochemical properties underneath some perennial plants. 


\section{MATERIALS AND METHODS}

\section{Site study}

The study was conducted at the southern area of Merapi volcano in Cangkringan Subdistrict of Sleman District, Yogyakarta, Indonesia situated at $7^{\circ} 34^{\prime} 32,216^{\prime \prime}$ to $7^{\circ} 40^{\prime} 24,511^{\prime}$ south latitude and $110^{\circ} 26^{\prime} 51,967^{\prime \prime}$ to $110^{\circ} 28^{\prime} 8,793$ east longitude and with altitude at the range of 500-1100 m above sea level (Figure 1). The soil samples and the earthworms were collected from the soil underneath the stands of some perennial plants such as; $A$. decurrens, Albizia chinensis, bamboo, coffee, fruit snake, and A. mangium. Each stand was taken as many as three samples in the area.

\section{Sampling the earthworms}

The collection of earthworm was carried out by hand sorting method, namely by digging the soil with an area of $30 \times 30 \mathrm{~cm}$ with a depth of $20 \mathrm{~cm}$. Earthworms were collected from the soil at depths of $0-10$ and $10-20 \mathrm{~cm}$, the earthworm found in each layer were collected and cleaned with water, then the number was counted. The number of earthworms obtained is converted into ind. $\mathrm{m}^{-2}$ to obtain the density of their population. Adult earthworms that have been cleaned from the soil are then made relaxed by putting them in ice water after which the length is measured, the put in a sample bottle that contains $4 \%$ formalin, after which it is preserved with $70 \%$ alcohol (Rai 2015) for further identification. The identification of earthworms was carried out with the guidelines of Edwards and Lofty (1977) and Hanafiah et al. (2010). The earthworm diversity was expressed in H' index (Shannon-Wienner's index) representing the number that resulted from the comparison of individuals of the same species and all of the existing species. It was calculated using the formula:

$$
H^{\prime}=-\Sigma_{i=1}\left[\left(\frac{n i}{n}\right) \operatorname{Ln}\left(\frac{n i}{n}\right)\right],
$$

Where; H': diversity index, ni: the number of the individuals of the-i and $\mathrm{N}$ : the number of the individuals of all species (Fachrul 2008). Soil temperature was measured using digital stick thermometer and soil moisture was measured using moisture meter. Measurement of soil temperature and moisture was done by placing each device into the soil at a depth of $0-10 \mathrm{~cm}$ and $10-20 \mathrm{~cm}$.

The criteria of the range of the diversity index were:

$\mathrm{H}^{\prime}<1 \quad$ : Low diversity, poor, very low productivity as indicated by the presence of heavy pressure and unstable ecosystem.

$1<\mathrm{H}^{\prime}<3$ : Medium diversity, sufficient productivity, sufficiently balanced ecosystem with medium ecological pressure.

H'>3 : High diversity, stable ecosystem, high productivity, resistance to ecological pressure.

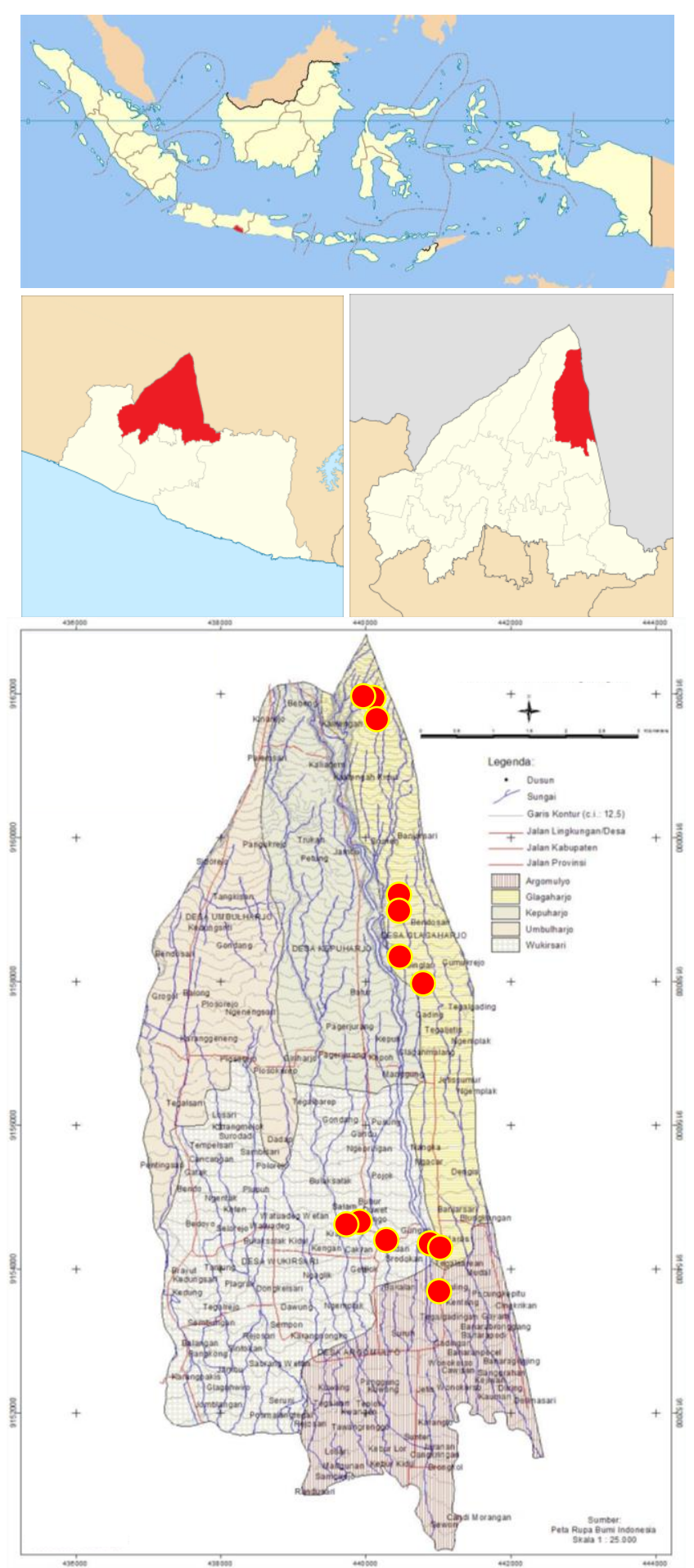

Figure 1. Soil and earthworms sampling location at the southern area of Merapi volcano in Cangkringan Subdistrict of Sleman District, Yogyakarta, Indonesia

\section{Soil analysis}

The samples collected from $0-10 \mathrm{~cm}$ and $10-20 \mathrm{~cm}$ in depth were air-dried and ground to pass through 2 and 0.5 $\mathrm{mm}$ sieve. The texture was analyzed by pipette method, and bulk density (BD) was measured on an oven-dry weight basis of a 100-ml core sample taken at field-moist conditions (Okalebo et al. 1993). Soil pH was determined in suspensions of $\mathrm{H}_{2} \mathrm{O}$ (soil: solution ratio 1:2.5) with a 
glass electrode after two $\mathrm{h}$ of mechanical shaking (ISRIC 2002). The C-organic content was analyzed using loss-onignition method (Salehi et al. 2011), total $\mathrm{N}$ was measured using the Kjeldahl method (ISRIC 2002), the available P was determined by Bray 1 method (Eviati and Sulaeman 2012), the mineralized $C$ (Anderson 1982), mineralized $N$ (Keeney and Wilson 1982). Exchangeable base cations $(\mathrm{Ca}, \mathrm{Mg}, \mathrm{K}$, and $\mathrm{Na}$ ) were extracted with $1 \mathrm{M}$ ammonium chloride and determined in the leachate by atomic absorption spectroscopy (AAS) for $\mathrm{Ca}$ and $\mathrm{Mg}$, while for $\mathrm{K}$ by flame photometer.

\section{RESULTS AND DISCUSSION}

\section{Soil moisture and temperature condition}

The recorded soil temperature and moisture in the studied areas were summarized in Table 1. The vegetation types had significant impact on the soil moisture and the temperature (Sen and Oturk 2017). The moisture content of the soils underneath the stand of the annual crop could be sequenced as follows: fruit snake > coffee > bamboo > A.chinensis $>$ A. decurrens $\approx$ A.mangium. At soil depths of $0-10$ and $10-20 \mathrm{~cm}$ had a similar trend in soil moisture. The high soil moisture level under the stands of fruit snake and coffee is due to the interconnected leaf canopy that shades the ground beneath it, causing the sun radiance unable to penetrate directly to the soil. Additionally, the higher clay content of the soil was highly capable of binding water that resulted in high moisture.

Type vegetation has a very significant effect on soil moisture and temperature. Soil moisture under the stand of Fruit snake > Coffee > Bamboo. > A.chinensis >A. decurrens $\approx A$. mangium at a soil depth of $0-10 \mathrm{~cm}$. Likewise the sequence at a depth of $10-20 \mathrm{~cm}$. High soil moisture in the soil below the fruit snake and coffee stands is caused by inhibition of evaporation because the soil surface is covered by the interlocking canopy of Fruit snake and Coffee leaves. This is different from other types of stands which have narrower leaf widths so that sunlight hits the soil surface directly as a result of large evaporation.

The soil temperatures tend to fluctuate with altitude The higher a place, the smaller the light intensity that reaches the surface so that the soil temperature will drop. The result of Purwantara (2015) states that the difference in air temperature based on altitude still follows the Braak formula, which is that every $100 \mathrm{~m}$ increase in air temperature drops $0.610^{\circ} \mathrm{C}$. The soil underneath the stand of the A. decurrens growing at an altitude of $1.173 \mathrm{~m}$ asl possess the lowest temperature. In general, the soil temperatures at depths of $0-10$ and $10-20 \mathrm{~cm}$ below the annual crop had the same tendency that was A. mangium > Coffee > Fruit snake. > Bamboo. > A. chinensis > A.decurrens.

\section{The type and density of earthworms}

The earthworm abundance and distribution are strongly influenced by the environmental conditions and the ecological status of the system (Pelosi et al. 2015). The result of earthworm identification was carried out using the guidelines of Edwards and Lofty (1985) and Hanafiah et al. (2010), there were three families of the earthworms identified, namely: Megascolecidae, Acanthodrilidae, and Lumbricidae. The family Megascolecidae of the genus Pheretima consisted of two species, namely: Pheretima hamayana and Pheretima californica. The family Acanthodrilidae of the genus Eudrillus possess the species Eudrillus eugeniae. The family Lumbricidae was represented by the genus Eiseniella of the species Eiseniella tetraeda. Each of them was illustrated in Figure 2.

The density and diversity index of earthworms underneath the stands of some perennial plants was presented in Table 2. Mostly earthworms found at the depth of $0-10 \mathrm{~cm}$, while at the depth of $10-20 \mathrm{~cm}$ just in a few numbers (in the range of 3.7 to 6.7 ind. $\mathrm{m}^{-2}$ ) and only observed in the soil underneath the stands of A. decurrens, coffee, and A. chinensis. The abiotic factors like $\mathrm{pH}$, moisture, soil texture and organic carbon have strong positive effect on the distribution of earthworm (Singh et al. 2016a). Earthworm biodiversity and distribution have been found to be positively correlated with type of vegetation and moisture content at the different collection sites and also varied according to soil habitat, soil tillage and land used pattern (Singh et al. 2016b). Research conducted by Tongkaemkaew et al. (2018) states that earthworms were found in the topsoil. Organic matter is the main energy source for the activity of the earthworms (Chauhan 2014). The distribution of the organic matter in the soil influenced the distribution pattern of the earthworms. The organic C content at the depth of 10-20 $\mathrm{cm}$ of the soil underneath the stands of A. mangium, A. chinensis and fruit snake was lower than that at the depth of $0-10 \mathrm{~cm}$ so that more earthworms presented at the layer.

Table 1. The temperature and the moisture of the soil underneath the stands of some forest trees

\begin{tabular}{lccccc}
\hline \multicolumn{1}{c}{ Types of vegetation } & $\begin{array}{c}\text { Altitude of the studied } \\
\text { area (m asl) }\end{array}$ & \multicolumn{2}{c}{ Soil Moisture (\%) } & \multicolumn{2}{c}{ Soil Temperature $(\mathbf{0} \mathbf{C})$} \\
\cline { 3 - 6 } & 1173 & $13.00 \mathrm{c}$ & $13.33 \mathrm{c}$ & $20.93 \mathrm{c}$ & $21.23 \mathrm{c}$ \\
\hline A. decurrens & 728 & $31.67 \mathrm{~b}$ & $27.00 \mathrm{~b}$ & $24.83 \mathrm{ab}$ & $24.80 \mathrm{ab}$ \\
Coffee & 763 & $13.00 \mathrm{c}$ & $13.00 \mathrm{c}$ & $25.40 \mathrm{a}$ & $26.50 \mathrm{a}$ \\
A. mangium & 833 & $14.67 \mathrm{c}$ & $14.33 \mathrm{c}$ & $23.17 \mathrm{~b}$ & $23.87 \mathrm{~b}$ \\
A. chinensis & 452 & $19.33 \mathrm{bc}$ & $17.33 \mathrm{bc}$ & $23.37 \mathrm{~b}$ & $23.53 \mathrm{~b}$ \\
Bamboo & 482 & $54.00 \mathrm{a}$ & $66.67 \mathrm{a}$ & $23.83 \mathrm{ab}$ & $24.27 \mathrm{~b}$ \\
Fruit snake & &
\end{tabular}

Note: Mean value followed by different letter was statistically based on Duncan different at 0.05 level 


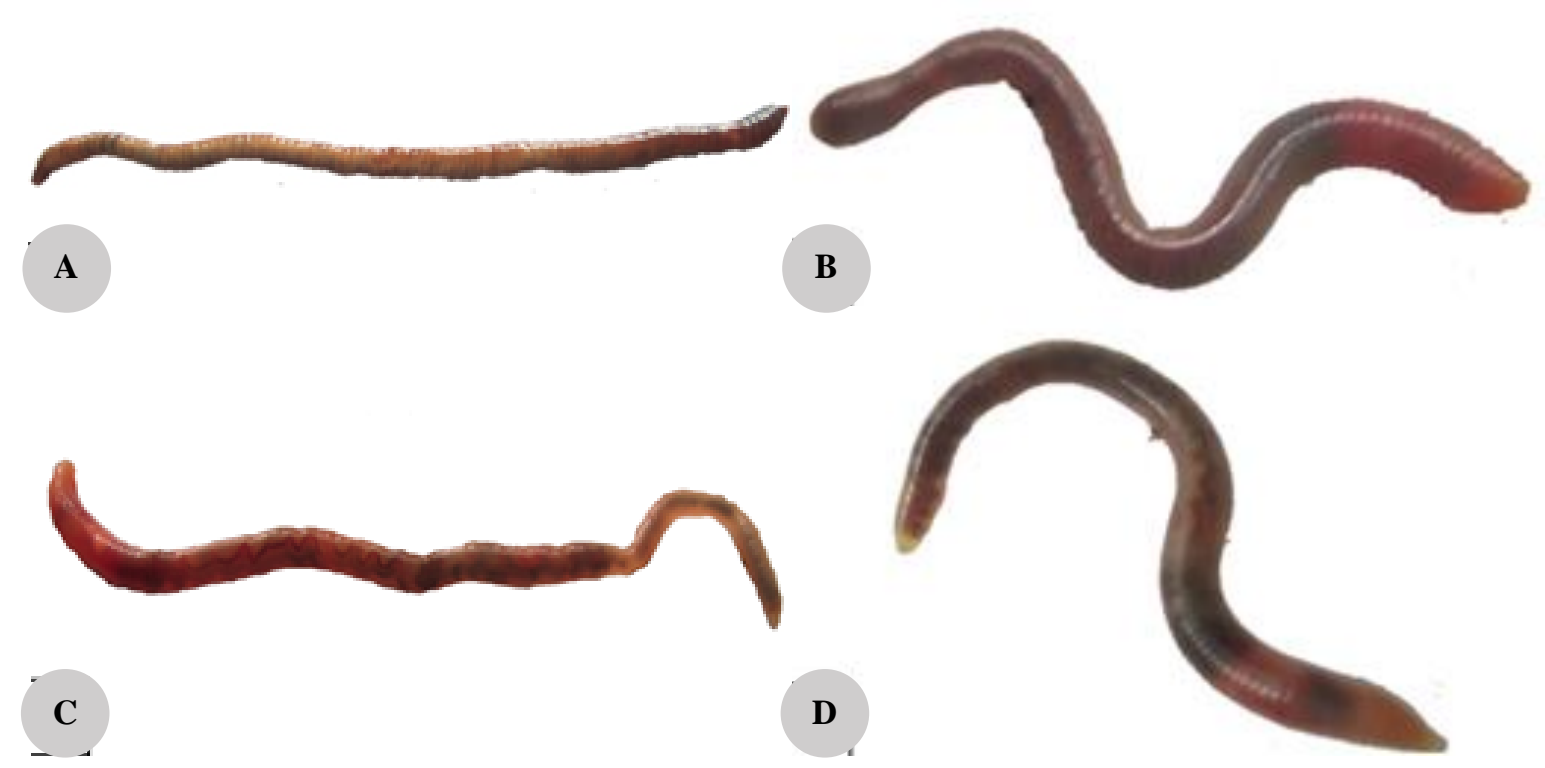

Figure 2. Four species identified in the studied area, namely: A. P. hamayana, B. P. californica sp., C. E. eugeniae, D. E. tetraeda

Table 2. Population earthworm under the stands of some perennial plants

\begin{tabular}{lcccc}
\hline \multirow{2}{*}{$\begin{array}{c}\text { Types of } \\
\text { vegetation }\end{array}$} & \multicolumn{3}{c}{$\begin{array}{c}\text { Earthworm density } \\
\text { (ind.m }\end{array}$} & \\
\cline { 2 - 4 } & $\begin{array}{c}\mathbf{0 - 1 0} \\
\text { cm }\end{array}$ & $\begin{array}{c}\mathbf{1 0 - 2 0} \\
\text { cm }\end{array}$ & Total & $\begin{array}{c}\text { Index of Shannon- } \\
\text { Winner }\left(\mathbf{H}^{\prime}\right)\end{array}$ \\
\hline A.decurens & 37.0 & 3.7 & 40.7 & 1.090 \\
Coffee & 98.7 & 6.7 & 105.4 & 1.095 \\
A.mangium & 37.0 & 0.0 & 37.0 & 1.030 \\
A. chinensis & 63.0 & 3.7 & 66.7 & 0.687 \\
Bamboo & 40.7 & 0.0 & 40.7 & 0.586 \\
Fruit snake & 92.6 & 0.0 & 92.6 & 0.686 \\
\hline
\end{tabular}

The life of earthworms is strongly influenced by environmental conditions such as humidity, temperature, and soil physicochemical properties (Hackenberger and Hackenberger 2014). The highest population of earthworm was observed in the soil underneath coffee plant around 105.7 ind. $\mathrm{m}^{-2}$. The second-largest population of the earthworm was found under the stand of fruit snake. Both of these commodities have an interlocking leaf canopy so that the soil surface is covered by a canopy, this causes soil moisture to be high enough so that earthworms can live and develop optimally. Other than that farmers often applied cow manure on coffee and fruit snake crops to increase productivity, while the other plants were not fertilized at all. The treatment had implications to the earthworm population in the soil understands of coffee and fruit snake was higher than other plants. Therefore the earthworm population under the annual crop could be sorted as follows: coffee $>$ fruit snake $>$ A. chinensis $>$ Bamboo $\approx A$. decurrens $>$ A. mangium.

The diversity index of the earthworms ranged from low to medium (Fachrul 2008; Brower et al. 1998). The diversity index of the earthworms in the soil underneath the stands of Coffee >A. decurrens > A. mangium $>A$. chinensis $>$ Fruit snake > Bamboo. Singh et al. (2016b) revealed that biodiversity and distribution of earthworms were positively correlated with vegetation type and moisture content at different collection sites and also varied according to soil habitat, tillage (Briones and Schmidt 2017; Moos et al. 2017), and land-use patterns.

\section{The soil physical and chemical properties underneath the perennial plants}

The soil physical properties included the distribution of particle density and bulk density was summarized in Table 3 . The vegetation types had significant impact on the bulk density at each soil depth and on the distribution of the particle density of the soil at the depth of $0-10 \mathrm{~cm}$, but had insignificant impact at the depth of $10-20 \mathrm{~cm}$. The soil texture class was at range of sandy loam to sandy clayey loam.

The bulk density (BD) varied with the composition and the proportion of the soil composing materials. The bulk density was at ranged of 1.22-1.60 g. $\mathrm{cm}^{-3}$. The highest value was found in the soil underneath the stands of fruit snake and the lowest one was found in the soil underneath the stands of Bamboo. The higher the soil BD the higher the density of the soil because of it has a smaller pore amount.

The chemical properties of the soil underneath the stands of some forest trees were presented in Tables 4.A and 4.B. The vegetation types did not have any significant impact on $\mathrm{pH} / \mathrm{H}_{2} \mathrm{O}$. The $\mathrm{pH} / \mathrm{H}_{2} \mathrm{O}$ value was at ranged of 5.64-6.31 and according to Eviati and Sulaeman (2012) it was classified into acid to slightly acid. The $\mathrm{pH} / \mathrm{H}_{2} \mathrm{O}$ values of the soil underneath the stands of some perennial plants at the depth of $0-10 \mathrm{~cm}$ were arranged in the sequence of Coffee > Bamboo > A. chinensis > Fruit snake >A. mangium $>$ A. decurrens.

The vegetation types had significant impact on the organic- $\mathrm{C}$ content, the available $\mathrm{P}$ and $\mathrm{K}$ at the depth of 0 $10 \mathrm{~cm}$, but unsignificant impact at the depth of 10-20 cm. The soil C-organic content underneath of the stands of some perennial plants ranged from 1.41 to $3.86 \%$ and categorized into the criteria of low to high rate. The 
sequence of the soil C-organic content was as follow: Coffee > Bamboo > A. mangium > Fruit snake > A. chinensis > A. decurrens. The highest C-organic content was found in the soil under the stands of Coffee. It was related to the $\mathrm{C}$ resources not only from the litter of the coffee, but also from the cow manure applied once in 6 months by the farmer.

The available $\mathrm{P}$ in the soil was at ranged of $2.47-60.52$ ppm (very low to high rate). The sequence of the $\mathrm{P}$ content in the soil underneath the stands of the Fruit snake $>$ Coffee $>$ A. decurrens $>$ A. mangium $>$ A. chinensis $>$ Bamboo. In general, the maximum availability of $\mathrm{P}$ was found in the soil with the $\mathrm{pH}$ ranging from 5.5 to 7.0 and its availability decreased if the $\mathrm{pH}$ of the soil was lower than 5.5 or higher than 7.0. Additionally, the decomposition of the organic matter producing organic acid and $\mathrm{CO}_{2}$ could increase the $\mathrm{P}$ availability in the soil.

The available potassium content in the soil was at ranged from very low to medium rate. The sequence of the potassium content underneath the stands of Coffee $>$ Fruit snake > Bamboo > A. mangium >A. chinensis $>A$. decurrens. The highest potassium content was found in the soil underneath the stands of Coffee and Fruit snake and it might be the result of the application of the cow manure once in 6 months.

The vegetation types had unsignificant impact on the total $\mathrm{N}$ content at the depth of $0-10 \mathrm{~cm}$, but significant at the depth of $10-20 \mathrm{~cm}$. The total $\mathrm{N}$ content in the soil underneath the stands of some perennial plants was ranged from low to medium rate ( 0.10 to $0.25 \%)$. The sequence of the total $\mathrm{N}$ content of the soil underneath the forest trees was Bamboo > Coffee > A. chinensis > Fruit snake >A. decurrens $>A$. mangium. The highest total $\mathrm{N}$ content was obtained on the soil under the stands of Bamboo, as the litter of this plant also contained a relatively high $\mathrm{N}$ of $2.73 \%$ (Baroroh et al. 2015). Tu et al. (2014) also asserted that $\mathrm{N}$ returned to the soil in the form of leaves, stems and branches of Bamboo was $5.07 \mathrm{~g} \mathrm{~m}^{-2}$ year $^{-1}$.

The vegetation types had very significant impact on the available $\mathrm{Ca}$ and $\mathrm{Mg}$ contents. The available $\mathrm{Ca}$ content in the soil was categorized into very low with the following sequence: Coffee $>$ Fruit snake $>$ Bamboo $>$ A. mangium $>$ A. chinensis >A. decurrens. The available $\mathrm{Ca}$ resulted from volcanic material coming from the eruption of the volcano in 2010. However, the available $\mathrm{Ca}$ decline due to leaching process.

Magnesium is an important element in the chemical structure of chlorophylls. The magnesium was required by plants for their enzymatic activities related to carbohydrate metabolism and especially citric acid cycle that played an important role in cell respiration (Guo et al. 2016). The available $\mathrm{Mg}$ content in the soil was ranged from low to high rate. The sequence of the $\mathrm{Mg}$ content of the soil underneath the forest trees was as follow: coffee $>$ Fruit snake $>$ Bamboo $>$ A. mangium $>$ A. chinensis $>$ A. decurrens .

The vegetation types had very significant impact on mineralized $\mathrm{C}$ and $\mathrm{N}$ content, either at depth of $0-10 \mathrm{~cm}$ or $10-20 \mathrm{~cm}$. The mineralized $\mathrm{C}$ ranged from $1.30-11.30 \mathrm{mg}$ $\mathrm{CO}_{2}$. The sequence of the mineralized $\mathrm{C}$ content of the soil underneath the stands of the perennial plants was as follow:
Coffee > Fruit snake > Bamboo > A. chinensis > A.decurrens $>$ A.mangium. While mineralized $\mathrm{N}$ ranged from 1.08-4.84 mg. $\mathrm{kg}^{-1}$. The sequence of the $\mathrm{N}$-mineralized content of the soil underneath the stands of the perennial plants was as follow: A.decurrens $>$ A.mangium $>$ Coffee $>$ A. chinensis $>$ Bamboo $>$ Fruit snake.

\section{The correlation of soil properties and the earthworm population}

The correlation of the environmental factors and the density of the earthworm population were summarized in Table 5. The results of the correlation analysis showed that the mineralized $\mathrm{C}$ significantly correlated to the density of the population of the earthworms. The mineralized carbon or soil respiration was one form of the labile organic $\mathrm{C}$ as a reflection of soil microorganism activity. The greater the respiration of the soil indicated that the number of microorganisms present in the soil was also greater. Brown (1995) states that earthworms can affect the population of microflora and fauna in the soil directly or indirectly through three main mechanisms: (i) commination, burrowing and casting; (ii) grazing; (iii) dispersal. Uvarov (2016) also mentioned that the presence of earthworms resulted in the respiration of soil systems tended to increase.

The soil moisture also significantly correlated to the density of the earthworms population. Bessolitsyna (2012) studied the effect of soil moisture and different soil types in the landscape of southern middle Siberia and found that the abundance and distribution of earthworms were mainly affected by soil moisture. Fulfilling their requirement of the soil's moisture, they would move deeper to the soil with more moisture when the surface of the ground was dry. Lalthanzara et al. (2011) suggested that there was different fluctuation of the density of the earthworm's population along with the change of the soil moisture in different months.

The available $\mathrm{K}$ and $\mathrm{Mg}$ in the soil also significantly correlated to the density of the earthworm's population. It was consistent with the results of the studies by Lalthanzara et al. (2011) and Kanianska et al. (2016). Zhu et al. (2013) showed that earthworms could activate and change $\mathrm{K}$ and $\mathrm{Mg}$ into the ones that were easier uptake-by the plants through their activities of consuming, digesting, absorbing and excreting nutrients.

It was different from the results of the studies by Chauhan (2014) showing that there was a close correlation between the density of the earthworms population and the organic matter content. The results of the study showed that there was not any significant correlation between the total organic matter content and the density of the earthworm population. Probably, it correlated to the palatability or the likeness of the earthworms in consuming the nutrients from the litter (Rief et al. 2012). Yatso and Lilleskov (2016) found that the litter and the soil type significantly influenced the development of the earthworms. The earthworms ate the nutrients resulting from the organic matter with various $\mathrm{C} / \mathrm{N}$ ratios, but they prefer organic matter with a low $\mathrm{C} / \mathrm{N}$ ratio. The litter of the falling leaves on the surface of the ground was generally with a high $\mathrm{C} / \mathrm{N}$ ratio. 
Table 3. The bulk density, soil fraction percentage and texture class of the soil

\begin{tabular}{|c|c|c|c|c|c|c|c|c|c|}
\hline \multirow{3}{*}{ Types of vegetation } & \multirow{2}{*}{\multicolumn{2}{|c|}{$\frac{\text { Bulk Density }}{\left(\text { g.cm }^{-3}\right)}$}} & \multicolumn{6}{|c|}{ Soil Fractions } & \multirow{3}{*}{ Texture class } \\
\hline & & & Sanc & $\%$ & Sil & $\%)$ & Cla & $(\%)$ & \\
\hline & \multicolumn{7}{|c|}{$(\mathbf{c m})$} & $10-20$ & \\
\hline A. decurrens & $1.56 \mathrm{ab}$ & $1.42 \mathrm{abc}$ & $68.83 \mathrm{abc}$ & $59.99 \mathrm{a}$ & $26.40 \mathrm{a}$ & $33.75 \mathrm{a}$ & $4.77 \mathrm{c}$ & $6.26 \mathrm{~b}$ & Sandy loam \\
\hline Coffee & $1.39 \mathrm{bc}$ & $1.37 \mathrm{bc}$ & $63.87 \mathrm{bcd}$ & $64.37 \mathrm{a}$ & $29.70 \mathrm{a}$ & $27.88 \mathrm{a}$ & $6.43 c$ & $7.75 b$ & Sandy loam \\
\hline A. mangium & $1.47 \mathrm{ab}$ & $1.46 \mathrm{ab}$ & $77.41 \mathrm{ab}$ & $80.17 \mathrm{a}$ & $10.80 \mathrm{~b}$ & $9.73 \mathrm{a}$ & $11.80 \mathrm{c}$ & $10.10 \mathrm{~b}$ & Sandy loam \\
\hline A. chinensis & $1.47 \mathrm{ab}$ & $1.50 \mathrm{ab}$ & $82.41 \mathrm{a}$ & $80.83 \mathrm{a}$ & $9.47 b$ & $8.78 \mathrm{a}$ & $8.12 \mathrm{c}$ & $10.39 b$ & Sandy loam \\
\hline Bamboo & $1.22 \mathrm{c}$ & $1.22 \mathrm{c}$ & $56.95 \mathrm{~cd}$ & $58.89 \mathrm{a}$ & $20.85 \mathrm{ab}$ & $16.63 \mathrm{a}$ & $22.20 \mathrm{~b}$ & $24.48 \mathrm{a}$ & Sandy clay loam \\
\hline Fruit snake & $1.60 \mathrm{a}$ & $1.54 \mathrm{a}$ & $47.63 d$ & $47.87 \mathrm{a}$ & $18.57 \mathrm{ab}$ & $16.44 \mathrm{a}$ & $33.80 \mathrm{a}$ & $35.69 \mathrm{a}$ & Sandy clay loam \\
\hline
\end{tabular}

Table 4.A. The chemical properties of the soil underneath the stands of some perennial plants

\begin{tabular}{|c|c|c|c|c|c|c|c|c|c|c|}
\hline \multirow[b]{2}{*}{$\begin{array}{c}\text { Types of } \\
\text { vegetation }\end{array}$} & \multicolumn{2}{|c|}{$\mathrm{pH} / \mathrm{H}_{2} \mathrm{O}$} & \multicolumn{2}{|c|}{ C-org (g.kg $\left.{ }^{-1}\right)$} & \multicolumn{2}{|c|}{ Total N (g.kg $\left.{ }^{-1}\right)$} & \multicolumn{2}{|c|}{$\mathrm{P}_{2} \mathrm{O}_{5}\left(\mathrm{mg} \cdot \mathrm{kg}^{-1}\right)$} & \multicolumn{2}{|c|}{ Available K (meq 100g $\left.\mathrm{g}^{-1}\right)$} \\
\hline & $0-10$ & $10-20$ & 0-10 & $10-20$ & 0-10 & $\begin{array}{l}10-20 \\
(\mathrm{~cm})\end{array}$ & 0-10 & $10-20$ & 0-10 & $10-20$ \\
\hline A. decurrens & $5.7 \mathrm{a}$ & $5.64 a$ & $14.03 \mathrm{~b}$ & $22.98 \mathrm{a}$ & $1.10 \mathrm{a}$ & $1.88 \mathrm{abc}$ & $15.16 \mathrm{~b}$ & $5.17 \mathrm{a}$ & $0.04 b c$ & $0.03 \mathrm{a}$ \\
\hline Coffee & $6.3 \mathrm{a}$ & $6.14 \mathrm{a}$ & $38.53 a$ & $33.04 \mathrm{a}$ & $2.33 \mathrm{a}$ & $2.14 \mathrm{ab}$ & $35.44 \mathrm{ab}$ & $8.60 \mathrm{a}$ & $0.43 a$ & $0.21 \mathrm{a}$ \\
\hline A. mangium & $5.8 \mathrm{a}$ & $6.26 \mathrm{a}$ & $26.13 \mathrm{ab}$ & $16.59 \mathrm{a}$ & $0.98 \mathrm{a}$ & $1.11 \mathrm{~d}$ & $14.59 \mathrm{~b}$ & $12.58 \mathrm{a}$ & $0.07 \mathrm{abc}$ & $0.03 \mathrm{a}$ \\
\hline A. chinensis & $5.9 \mathrm{a}$ & $5.99 a$ & $16.52 b$ & $23.06 \mathrm{a}$ & $2.32 \mathrm{a}$ & $1.36 \mathrm{~cd}$ & $10.81 b$ & $2.47 \mathrm{a}$ & $0.041 \mathrm{c}$ & $0.02 \mathrm{a}$ \\
\hline Bamboo & $6.0 \mathrm{a}$ & $6.25 \mathrm{a}$ & $37.50 \mathrm{a}$ & $33.44 \mathrm{a}$ & $2.47 \mathrm{a}$ & $2.45 \mathrm{a}$ & $9.78 b$ & $2.66 \mathrm{a}$ & $0.27 \mathrm{abc}$ & $0.17 \mathrm{a}$ \\
\hline Fruit snake & $5.8 \mathrm{a}$ & $5.89 \mathrm{a}$ & $22.90 \mathrm{ab}$ & $20.61 \mathrm{a}$ & $1.41 \mathrm{a}$ & $1.52 \mathrm{bcd}$ & $60.52 \mathrm{a}$ & $59.47 \mathrm{a}$ & $0.39 \mathrm{ab}$ & $0.42 \mathrm{a}$ \\
\hline
\end{tabular}

Table 4.B. The chemical properties of the soil underneath the stands of some perennial plants

\begin{tabular}{|c|c|c|c|c|c|c|c|c|}
\hline \multirow[b]{2}{*}{$\begin{array}{c}\text { Types of } \\
\text { vegetation }\end{array}$} & \multicolumn{2}{|c|}{ Available Ca (meq 100g-1) } & \multicolumn{2}{|c|}{ Available Mg (meq $\left.100 \mathrm{~g}^{-1}\right)$} & \multicolumn{2}{|c|}{ Mineralized $\mathrm{C}\left(\mathrm{mgCO}_{2}\right)$} & \multicolumn{2}{|c|}{ Mineralized N (mg.kg-2) } \\
\hline & 0-10 & $10-20$ & 0-10 & $\begin{array}{l}10-20 \\
(\mathrm{~cm})\end{array}$ & 0-10 & $10-20$ & $0-10$ & $10-20$ \\
\hline A. decurrens & $0.073 \mathrm{c}$ & $0.110 \mathrm{~b}$ & $0.27 \mathrm{c}$ & $0.29 \mathrm{~b}$ & $2.10 \mathrm{~b}$ & $1.30 \mathrm{~b}$ & $4.84 \mathrm{a}$ & $4.11 \mathrm{a}$ \\
\hline Coffee & $1.507 \mathrm{a}$ & $0.900 \mathrm{a}$ & $6.78 \mathrm{a}$ & $5.53 \mathrm{a}$ & $11.30 \mathrm{a}$ & $11.20 \mathrm{a}$ & $2.63 b$ & $3.71 \mathrm{ab}$ \\
\hline A. mangium & $0.510 \mathrm{bc}$ & $0.193 \mathrm{~b}$ & $0.55 \mathrm{bc}$ & $0.25 \mathrm{~b}$ & $2.04 \mathrm{~b}$ & $2.20 \mathrm{~b}$ & $3.07 \mathrm{ab}$ & $2.35 \mathrm{bc}$ \\
\hline A. chinensis & $0.237 \mathrm{c}$ & $0.113 \mathrm{~b}$ & $0.31 \mathrm{c}$ & $0.20 \mathrm{~b}$ & $2.75 \mathrm{c}$ & $2.38 \mathrm{~b}$ & $1.80 \mathrm{~b}$ & $1.73 \mathrm{c}$ \\
\hline Bamboo & $0.780 \mathrm{~b}$ & $0.713 \mathrm{a}$ & $3.94 \mathrm{ab}$ & $3.51 \mathrm{ab}$ & $6.70 \mathrm{ab}$ & $6.58 \mathrm{ab}$ & $1.62 \mathrm{~b}$ & $1.52 \mathrm{c}$ \\
\hline Fruit snake & $1.030 \mathrm{ab}$ & $1.137 \mathrm{a}$ & $4.79 \mathrm{a}$ & $6.00 \mathrm{a}$ & $10.00 \mathrm{a}$ & $9.80 \mathrm{a}$ & $1.10 \mathrm{~b}$ & $1.08 \mathrm{c}$ \\
\hline
\end{tabular}

Note for Tables 3, 4.A, 4.B: Mean value followed by different letter was statistically based on Duncan different at 0.05 level.

Table 5. The coefficient correlation (r) of soil physico-chemical properties and earthworms' population.

\begin{tabular}{|c|c|c|}
\hline Soil parameter $(\mathbf{X})$ & Regression equation & $\begin{array}{c}\text { Coefficient } \\
\text { correlation }(\mathbf{r})\end{array}$ \\
\hline Moisture & $\mathrm{Y}=10.3+2.17 \mathrm{X}$ & $0.59 *$ \\
\hline Temperature & $Y=-29.68+3.85 X$ & 0.12 \\
\hline Bulk density & $Y=-59.56+84.35 X$ & 0.22 \\
\hline Clay & $Y=57.12+0.39 X$ & 0.07 \\
\hline Silt & $Y=59.97+0.15 X$ & 0.03 \\
\hline Sand & $Y=79.93-0.26 X$ & -0.07 \\
\hline $\mathrm{pH} \mathrm{H} \mathrm{H}_{2} \mathrm{O}$ & $Y=-438.2+83.79 X$ & 0.44 \\
\hline Organic C (C-org) & $Y=57.07+0.22 X$ & 0.05 \\
\hline Available P & $Y=43.34+0.84 X$ & 0.35 \\
\hline Total N & $Y=68.58-3.30 X$ & -0.05 \\
\hline Available K & $Y=36.93+125.14 X$ & $0.53 *$ \\
\hline Available $\mathrm{Na}$ & $Y=50.01+246.7 X$ & 0.16 \\
\hline Available $\mathrm{Ca}$ & $Y=24.46+55.57 X$ & $0.51 *$ \\
\hline Available Mg & $Y=34.90+10.04 X$ & $0.49 *$ \\
\hline Mineralized C & $Y=2.40+1.28 X$ & $0.82 * *$ \\
\hline Mineralized N & $Y=8.37-0.96 X$ & -0.06 \\
\hline
\end{tabular}

The earthworm population correlated unsignificantly with the mineralized and total $\mathrm{N}$. The earthworms played an important role in accelerating the decomposition process of the litter (Rief et al. 2012). The organic form of $\mathrm{N}$ transformed into the mineral form in the soil. The mineralized $\mathrm{N}$ consisted of $\mathrm{NH}_{4}$ (ammonium) and $\mathrm{NO}_{3}$ (nitrate). The nitrate was a mobile anion so easily leached out from the soil dominated by a sand fraction. In spite of ammonium as a cation, but is presented in the soil with low content of clay, so it will be easily leached.

In conclusion, the earthworms population at the upper area of Merapi volcano was significantly influenced by the types of vegetation with the following sequence: Coffee > Fruit snake $>$ A. chinensis $>A$. decurrens $\approx$ Bamboo $>A$. mangium. -There were four species of the earthworm found in the location of the study: P. hamayana, P. californica, E. eugeniae, and E. tetraeda. The diversity index of the earthworms in the soil underneath the stands of Coffee $>A$. mangium $>$ A. chinensis $\approx$ Fruit snake $>$ Bamboo. The physical and chemical properties of the soil positively correlated to the density of the population of the earthworms, which were mineralized-C $\geq$ soil moisture $\geq$ 
available $\mathrm{K} \geq$ available $\mathrm{Ca} \geq$ available $\mathrm{Mg}$. The results could be concluded that the labile carbon, water, and alkaline cations were the important factors in improving the soil biological fertility in the upland area of an active volcano.

\section{ACKNOWLEDGEMENTS}

The author is grateful to Gadjah Mada University, Yogyakarta, Indonesia for providing financial assistance through project no. 2488/UN1.P.III/DIT-LIT/PT/2021.

\section{REFERENCES}

Agus C, Wulandari D. 2012. The abundance of pioneer and their interaction with endomycorrhiza at different land qualities after Merapi Eruption. J Trop For Manag. 18 (3): 145-154. DOI: 10.7226/jtfm.18.3.145.

Anderson, JPE. 1982. Soil respiration. In: Page AL, Miller RH, Keeney DR (eds). Methods of Soil Analysis, Part 2. Chemical and Microbiological Properties-Agronomy Monograph no. 9. Madison. USA.

Baroroh A, Setyono P, Setyaningsih R. 2015. An analysis of macronutrient content in compost of bamboo leaves litter and solid waste of sugar factory (blotong). Bioteknologi 12 (2): 46-51. DOI: 10.13057/biotek/c120203.

Bartz MLC, Passini A, Brown GD. 2013. Earthworms as soil quality indicators in Brazilian no-tillage systems. Appl Soil Ecol 69: 39-48. DOI: 10.1016/j.apsoil.2013.01.011.

Bessolitsyna EP. Ecological and geographic distribution patterns of earthworms (Oligochaeta, Lumbricidae) in landscapes of southern middle Siberia. Russ J Ecol 43 (1): 82-85. DOI: 10.1134/S106741361106004X.

Blouin M, Hodson ME, Delgado EA, Baker G, Brussaard L, Butt KR, Dai J, Dendooven L, Peres G, Tondoh JE, Cluzeu D, Brun JJ. 2013. A review of earthworm impact on soil function and ecosystem services. Eur J Soil Sci 64 (2): 161-182. DOI: 10.1111/ejss.12025.

Briones M, Schmidt O. 2017. Conventional tillage decreases the abundance and biomass of earthworms and alters their community structure in a global meta-analysis. Glob Change Biol 23: 43964419. DOI: $10.1111 / \mathrm{gcb} .13744$.

Brower JE, Zar JH, Von Ende CN. 1997. Field and Laboratory Method for General Ecology. Brown Publishers, Boulevard Dubuque, Cogger

Cesarz S, Craven D, Dietrich C, Eisenhauer N. 2016. Effect of soil and leaf litter quality on the biomass of two endogeic earthworm species. Eur J Soil Biol 77: 9-16. DOI: 10.1016/j.ejsobi.2016.09.002.

Chauhan RP. 2014. Role of earthworms in soil fertility and factors affecting their population dynamic: A review. J Recent Adv Agr 2 (7): $277-284$

Chauhan RP, Pande KR, Shah SC, Dhakal DD. 2014. Earthworms as an alternative technique for soil fertility evaluation. Sch J Agric Vet Sci 1 (3): 130-136

Edwards CA, Lofty JR. 1977. Biology of Earthworms. In Biology of Earthworm. Springer, USA. DOI: 10.1007/978-1-4613-3382-1.

Edwards CA, Lofty JR. 1985. Biology of Earthworm. Chapman and Hall, London.

Eviati, Sulaeman. 2012. Chemistry Analysis of Soil, Plant, Water and Fertilizers. Indonesian Agency for Agricultural Research and Development, Bogor. [Indonesian].

Fachrul MF. 2008. Method of Biotechnology Sampling. Bumi Aksara, Bandung. [Indonesian]

Frouz J. 2017. Effect of soil macro-and mesofauna on litter decomposition and soil organic matter stabilization. Geoderma 332: 161-172 DOI: 10.1016/j.geoderma.2017.08.039.

Guo W, Nazim H, Liang Z, Yang D. 2016. Magnesium deficiency in plants: An urgent problem. Crop J 4: 83-91. DOI: 10.1016/j.cj.2015.11.003.

Hackenberger DK, Hackenberger BK. 2014. Earthworm community structure in grassland habitats differentiated by climate type during two consecutive seasons. Eur J Soil Biol 61:27-34. DOI: 10.1016/j.ejsobi.2014.01.001.

Hanafiah KA, Napoleon A, Ghofar N. 2010. Soil Biology: Soil Ecology \& Macrobiology. Raja Grafindo Persada, Jakarta. [Indonesian]

Tu L, Hu H, Hu T, Zhang J, Li X, Liu L, Xiao L, Chen G, Hong R. 2014. Litterfall, litter decomposition, and nutrient dynamics in two subtropical bamboo plantations of China. Pedosphere 24 (1): 84-97. DOI: 10.1016/S1002-0160(13)60083-1.

Idjuddin AA, Erfandi D, Soelaeman Y, Suwanda MH, Suganda H. 2012. Rehabilitasi dan konservasi tanah pasca-erupsi Gunung Merapi. In: Noor M, Mamat HS, Sarwani M (eds). Kajian Cepat Dampak Erupsi Gunung Merapi 2010 terhadap Sumberdaya Lahan Pertanian dan Inovasi Rehabilitasinya. Badan Penelitian dan Pengembangan Pertanian, Jakarta. [Indonesian]

ISRIC. 2002. Procedures for Soil Analysis. ISRIC Technical Paper. Food and Agriculture Organization, Rome.

Jousset P, Pallister J, Surono. 2013. The 2010 eruption of Merapi volcano. J Volcanol Geotherm Res 261: 1-6. DOI: 10.1016/j.jvolgeores.2013.05.008.

Kanianska R, Jad'ud'ova J, Makovnikova J, Kizekova M. 2016. Assessment of relationship between earthworms and soil abiotic and biotic factor as a tool in sustainable agriculture. Sustainability 8 (9): 906. DOI: 10.3390/su8090906.

Keeney DR, Wilson DW. 1982. Nitrogen-inorganic forms. In: Page AL, Miller RH, Keeney DR (eds.). Methods of Soil Analysis, Part 2. Chemical and Microbiological Properties-Agronomy Monograph No. 9. American Society of Agronomy, Madison, USA.

Lalthanzara H, Ramanujam SN, Jha LK. 2011. Population dynamics of earthworms in relation to soil physic-chemical parameters in agroforestry system of Mizoram, India. J Environ Biol 32 (5): 599605.

Moos JH, Schrader S, Paulsen HM. 2017. Reduced tillage enhances earthworm abundance and biomass in organic farming: A metaanalysis. Appl Agric For Res. DOI: DOI: 10.3220/LBF1512114926000.

Okalebo JR, Gathua KW, Woomer PL. 1993. Laboratory methods of soil and plant analysis: A working manual. Soil Science Society of East Africa Technical Publication No. 1 UNESCO/Rosta. Nairobi, Kenya.

Peres G, Vandenbulcke F, Guernion M et al. 2011. Earthworm indicators as tools for soil monitoring, characterization and risk assessment. An example from the national bioindicator programme (France). Pedobiologia 54: 77-87. DOI: 10.1016/j.pedobi.2011.09.015.

Pelosi C, Bertrand M, Thenard J, Mougin C. 2015. Earthworms in a 15 year agricultural trial. Appl Soil Ecol 88: 1-8 DOI: 10.1016/j.apsoil.2014.12.004.

Purwantara S. 2015. Studi temperatur udara terkini di wilayah Jawa Tengah dan DIY. Geomedia 13: 1. DOI: 10.21831/gm.v13i1.4476

Rai SN. 2015. Earthworm biodiversity in different land-use system. International J Res Granthaalayah 5 (6): 347-352. DOI: 10.29121/granthaalayah.v5.i6.2017.2041.

Rief A, Knapp BA, Seeber J. 2012. Palatability of selected alpine plant litters for the decomposer Lumbricus rubellus (Lumbricidae). PloS ONE 7 (9): e45345. DOI: 10.1371/journal.pone.0045345.

Salehi MH, Beni OH, Harchegani HB, Borujeni IE, Motaghian HR. 2011. Refining soil organic matter determination by loss-on-ignition. Pedosphere 21 (4): 473-482. DOI: 10.1016/S1002-0160(11)60149-5.

Sen C, Ozturk O. 2017. The relationship between soil moisture and temperature vegetation on Kirklareli City Luleburgaz District a natural pasture vegetation. Intl J Environ Agric Res (IJOEAR) 3 (3): 21-29.

Singh S, Singh J, Vig AP. 2016a. Earthworm as ecological engineers to change the physic-chemical properties of soil: Soil vs vermicast. Ecol Eng 90:1-5. DOI: 10.1016/j.ecoleng.2016.01.072.

Singh S, Singh J, Vig AP. 2016b. Effect of abiotic factors on the distribution of earthworms in different land use patterns. J Basic Appl Zool 74: 41-50. DOI: 10.1016/j.jobaz.2016.06.001.

Singh J. 2018. 3-Role of earthworm in sustainable agriculture. In: Galanakis CM (eds). Sustainable Food Systems from Agriculture to Industry. Academic Press, India. DOI: 10.1016/B978-0-12-8119358.00003-2.

Singh J, Schadler M, Demetrio W, Brown GG, Eisenhauer N. 2019. Climate change effects on earthworms-a review. Soil Org 91 (3): 114138. DOI: $10.25674 / \mathrm{so} 91$ iss3pp 114

Surono, Jousset P, Pallister J et al. 2012. The 2010 explosive eruption of Java's Merapi volcano-A '100-year' event. J Volcanol Geotherm Res 241-242: 121-135. DOI: 10.1016/j.jvolgeores.2012.06.018. 
Tongkaemkaew U, Sukkul J, Sumkhan J, et al. 2018. Litterfall, litter decomposition, soil macrofauna, and nutrient content in rubber monoculture and rubber-based agroforestry plantations. For Soc 2 (2): 138-149. DOI: 10.24259/fs.v2i2.4431.

Yatso KN, Lilleskov EA. 2016. Effect of tree leaf litter, deer fecal pellets, and soil properties on growth of an introduced earthworm (Lumbricus terrestris): Implications for invasion dynamics. Soil Biol Biochem 94: 181-190. DOI: 10.1016/j.soilbio.2015.11.030.

Zhu X, Lian B, Yang X, Liu C, Zhu L. 2013. Biotransformation of earthworm activity on potassium-bearing mineral powder. J Earth Sci 24: 65-74. DOI: 10.1007/s12583-013-0313-6. 